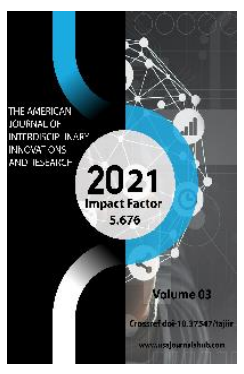

\title{
Prospects Of The Prognosis For The Legalization Of Informal Employment In Uzbekistan
}

\author{
Nuriddin Korabaev \\ PhD Student, Research Center Of "Scientific Bases And Issues Of Economic Development Of \\ Uzbekistan" Under The Tashkent State University Of Economics, Uzbekistan
}

\section{ABSTRACT}

On the basis of the constructed econometric model on the factors that determine the degree of employment in the informal sector, forecast indicators of the prospects for the development of the national labor market have been developed.

\section{KEYWORDS}

Formal sector, informal sector, informal employment, labor market.

\section{INTRODUCTION}

In our country the development of the innovative and digital economy leads to reduction of the unemployment, the adaptation of the informal sector and informal labor and also the prosperity of the stable economical advancement. In the Labour
Market distribution of labour resources, investigating and analyzing organizational and social spheres of public employment are considered as very significant points of these days. 
Analyzing and forecasting the trends in the Labor Market of Uzbekistan, appraising the highest level of socio-economic and political consequences of the informal employment are rather demandable.

In the resolution № 1011 “Identifying the number of unemployment, researching the unemployment section from the viewpoint of housekeeping and, also the improvement in originating the balance in the public employment and labor forces" issued by the Cabinet of Ministers in 2017 on December 22, it is formally approved to appraise the labor forces, an account, balances in forecasting and researching the mechanism of identifying the number of people in informal labor sector, organizing data collection on the structural quality and, from that time the investigation is in process. The President of the Republic of Uzbekistan highlighted in his application applied to The Upper House in 2020 on January 25 the informal labor sector and respectively mentioned" In the new tax system the tax burden is decresed up to 1.5 times. As a result the number of people in formal labor increased up tp 500 thousand times". 1

Although in Uzbekistan there was a strong industrial development the matter of informal labor was neglected, consequently, strong informal labor and its effect on different industrial spheres are staying steady.

In the labor market the employment rate of people and its degree are evaluated by the factor affecting on their improvement. The nain goal in the labor market is to make offers on ultimately decreasing informal sector by using the statistics and by using the factors affecting the degree formation of informal labor.

The factors affecting the informal sector in the labor market, the factors affecting the degree of informal labor of people are determined by using PEST anaysis.

First of all, five main factors affecting informal labor were determined in the labor market in order to conduct PEST anaysis. Statistical information between 2011-2020 of The Statistical Committee of Uzbekistan, The Tax Committee of Uzbekistan, The Ministry of Poverty Reduction and The Industrial development of Uzbekistan, The Ministry of Employment and Labor Relations was used for evaluation the importance of factors affecting on informal labor.

The factors in order to perform PEST analysis affecting informal labor of people in the formal sector are mentioned below:

- Gross income per captiva;

- A number of operating enterprises;

- An annual inremental increase in the labor force;

- The avarage annual rate of personal income tax;

- Consumer price index;

Statistical data on key factors affecting the informal sector for the period 2011-2020 were used perform the PEST analysis. 
Table: 1

Number of people employed in the formal sector in the Republic of Uzbekistan and amount of factors influencing it.

\begin{tabular}{|c|c|c|c|c|c|c|c|c|c|c|}
\hline Indicators & $\begin{array}{c}2011 \\
y .\end{array}$ & $\begin{array}{c}2012 \\
y .\end{array}$ & $\begin{array}{c}2013 \\
y .\end{array}$ & $\begin{array}{c}2014 \\
\text { y. }\end{array}$ & $\begin{array}{c}2015 \\
\text { y. }\end{array}$ & $\begin{array}{c}2016 \\
y .\end{array}$ & $\begin{array}{c}2017 \\
\mathrm{y} .\end{array}$ & $\begin{array}{c}2018 \\
\mathrm{y} .\end{array}$ & $\begin{array}{c}2019 \\
y .\end{array}$ & $\begin{array}{c}2020 \\
y .\end{array}$ \\
\hline $\begin{array}{c}\text { Number of } \\
\text { people } \\
\text { employed in the } \\
\text { informal sector } \\
\text { of the labor } \\
\text { market. A } \\
\text { thousand } \\
\text { people }(y)\end{array}$ & $\begin{array}{c}4193, \\
1\end{array}$ & $\begin{array}{c}4474 \\
4\end{array}$ & $\begin{array}{c}4699 \\
7\end{array}$ & $\begin{array}{c}4007 \\
2\end{array}$ & $\begin{array}{c}4207 \\
8\end{array}$ & $\begin{array}{c}4245 \\
2\end{array}$ & $\begin{array}{c}4185 \\
5\end{array}$ & $\begin{array}{c}5379 \\
8\end{array}$ & $\begin{array}{c}5368 \\
2\end{array}$ & $\begin{array}{c}5618 \\
8\end{array}$ \\
\hline $\begin{array}{l}\text { The amount of } \\
\text { real gross } \\
\text { income pre } \\
\text { captiva. A } \\
\text { thousand sums } \\
\text { (X1) }\end{array}$ & $\begin{array}{c}2118 \\
0\end{array}$ & $\begin{array}{c}2574 \\
8\end{array}$ & 3142,1 & $\begin{array}{c}3601 \\
3\end{array}$ & $\begin{array}{c}4805 \\
2\end{array}$ & $\begin{array}{c}5503, \\
5\end{array}$ & $\begin{array}{c}6227 \\
8\end{array}$ & $\begin{array}{c}7300 \\
2\end{array}$ & $\begin{array}{c}9008 \\
4\end{array}$ & $\begin{array}{c}10385 \\
, 9\end{array}$ \\
\hline $\begin{array}{c}\text { Number of } \\
\text { operating } \\
\text { enterpriclses. A } \\
\text { thousand } \\
\text { people }\left(\mathrm{X}_{2}\right)\end{array}$ & 228,7 & 229,2 & 241,2 & 246,7 & 257,8 & 268,4 & 285,5 & 323,5 & 398,1 & 475,2 \\
\hline $\begin{array}{c}\text { An annual } \\
\text { incremental } \\
\text { increase in the } \\
\text { labor force. A } \\
\text { thousand } \\
\text { people }\left(X_{3}\right)\end{array}$ & 560,4 & 277,9 & 249,8 & 233,9 & 228,1 & 212,8 & 177,4 & 163,3 & 119,4 & 193,3 \\
\hline $\begin{array}{c}\text { The avarage } \\
\text { annual rate of } \\
\text { personal income } \\
\text { tax*, \% (X4) }\end{array}$ & 16,0 & 15,7 & 15,3 & 15,2 & 16,2 & 15,8 & 15,8 & 12,0 & 12,0 & 12,0 \\
\hline $\begin{array}{c}\text { Consumer price } \\
\text { index, \% (X5) }\end{array}$ & 107,6 & 107,0 & 106,8 & 106,1 & 105,6 & 105,7 & 114,4 & 114,3 & 115,2 & 111,1 \\
\hline
\end{tabular}


*the average annual rate of personal income tax is taken as the average of the differentiated tax rates for 2011-2017.

Here the number of people employed in the informal sector of the labor market is determined by $(y)$.Factors influencing the real gross per capita income $\left(\mathrm{X}_{1}\right)$, the number of operating enterprises ( $\left.\mathrm{X}_{2}\right)$, the additional annual growth of the labor force (x3), the average annual personal income tax rate (x4), econometric analysis of the interaction of factors of the consumer price index $\left(\mathrm{X}_{5}\right)$ and an econometric model to determine the forecast results of the future situation will be developed.

Since the selected factor indicators are not homogeneous, we can determine the logarithmic values of the factor indicators. (The graph №-2)

\section{Table: 2}

The amount of natural and logarithmic indicators of performance and influencing factors in the Republic of Uzbekistan for 2011-20201

\begin{tabular}{|c|c|c|c|c|c|c|c|c|c|c|}
\hline Indicators & $\begin{array}{c}2011 \\
\text { y. }\end{array}$ & $\begin{array}{c}2012 \\
\text { y. }\end{array}$ & $\begin{array}{c}2013 \\
\text { y. }\end{array}$ & $\begin{array}{c}2014 \\
\text { y. }\end{array}$ & $\begin{array}{c}2015 \\
\text { y. }\end{array}$ & $\begin{array}{c}2016 y \\
.\end{array}$ & $\begin{array}{c}2017 \\
\text { y. }\end{array}$ & $\begin{array}{c}2018 \\
\text { y. }\end{array}$ & $\begin{array}{c}2019 \\
\text { y. }\end{array}$ & $\begin{array}{c}2020 \\
\text { y. }\end{array}$ \\
\hline $\begin{array}{l}\text { Number of } \\
\text { people employed } \\
\text { in the informal } \\
\text { sector of the } \\
\text { labor market., } \\
\text { million people (In } \\
\text { y) }\end{array}$ & 8,34 & 8,41 & 8,45 & 8,30 & 8,34 & 8,35 & 8,34 & 8,59 & 8,59 & 8,63 \\
\hline $\begin{array}{l}\text { The amount of } \\
\text { real gross income } \\
\text { pre captiva. A } \\
\text { thousand sums(In } \\
\left.x_{1}\right)\end{array}$ & 7,66 & 7,85 & 8,05 & 8,20 & 8,48 & 8,61 & 8,74 & 8,90 & 9,11 & 9,25 \\
\hline $\begin{array}{c}\text { Number of } \\
\text { operating } \\
\text { enterpriclses. A } \\
\text { thousand people } \\
(\operatorname{In} \times 2)\end{array}$ & 5,43 & 5,43 & 5,49 & 5,51 & 5,55 & 5,59 & 5,65 & 5,80 & 5,99 & 6,16 \\
\hline $\begin{array}{c}\text { An annual } \\
\text { incremental } \\
\text { increase in the }\end{array}$ & 6,33 & 5,63 & 5,52 & 5,45 & 5,43 & 5,36 & 5,18 & 5,10 & 4,78 & 5,26 \\
\hline
\end{tabular}

${ }^{1}$ O'zbekiston Respublikasi davlat statistika qo'mitasi hamda bandlik va mehnat munosabatlari vazirligi ma'lumotlari asosida muallif tomonidan tuzilgan. 
The American Journal of Interdisciplinary Innovations and Research (ISSN-2642-7478)

Published: May 31, 2021 | Pages: 168-179

Doi: https://doi.org/10.37547/tajiir/Volume03lssue05-28

\begin{tabular}{|c|l|l|l|l|l|l|l|l|l|l|}
\hline $\begin{array}{c}\text { labor force. A } \\
\text { thousand people } \\
\text { (In x3) }\end{array}$ & & & & & & & & & & \\
\hline $\begin{array}{c}\text { The avarage } \\
\text { annual rate of } \\
\text { personal income } \\
\text { tax, \% (In x4) }\end{array}$ & 2,77 & 2,75 & 2,76 & 2,72 & 2,79 & 2,76 & 2,76 & 2,49 & 2,49 & 2,49 \\
\hline $\begin{array}{c}\text { Consumer price } \\
\text { index, \% (In x5) }\end{array}$ & 4,68 & 4,67 & 4,67 & 4,66 & 4,66 & 4,66 & 4,74 & 4,74 & 4,75 & 4,71 \\
\hline
\end{tabular}

We determine the correlation coefficients in order to estimate the correlation density of the factors based on the determined logarithmic values.(the graph №-3).

Table: 3

The values of the correlation coefficient of the selected factors. ${ }^{2}$

\begin{tabular}{ccccccc}
\hline & $\operatorname{Ln} y$ & $\operatorname{Ln} x_{1}$ & $\operatorname{Ln} x_{2}$ & $\operatorname{Ln} x_{3}$ & $\operatorname{Ln} x_{4}$ & $\operatorname{Ln} x_{5}$ \\
\hline $\operatorname{Ln} y$ & 1 & & & & & \\
$\operatorname{Ln} x_{1}$ & 0,670165 & 1 & & & & \\
$\operatorname{Ln} x_{2}$ & 0,839225 & 0,910999 & 1 & & & \\
$\operatorname{Ln} x_{3}$ & $-0,54483$ & $-0,84922$ & $-0,67408$ & 1 & & \\
$\operatorname{Ln} x_{4}$ & $-0,92296$ & $-0,75749$ & $-0,8879$ & 0,61851 & 1 & \\
$\operatorname{Ln} x_{5}$ & 0,644434 & 0,67445 & 0,681325 & $-0,61668$ & $-0,71748$ & 1 \\
\hline
\end{tabular}

From the value of the double correlation coefficients, i.e., the strong link density between the resulting factor and the selected factors, and the presence of multicollenity with other factors in factors $X_{1}$ and $X_{4},\left(r_{X_{1}, X_{2}}=0,9109, \ldots, r_{X_{4}, X_{2}}=\right.$ 0,8879 ; ва $r_{X_{1}, X_{2}} \geq 0,8$;) as a rule, these exogenous factors were excluded from the model. The determination of the effect of the influencing factors on the outcome factor as well as the density of the mutual pair of correlations was continued without two factors excluded from the model. the problem of multicollinearity was solved by dropping the modifications. we will examine the solution to this problem again by examining the modifications in multicollinearity in the table below. the collarity between the modifications known from Table 4 below is significantly lower compared to the results in Table 3.

\footnotetext{
${ }^{2}$ Compiled by the author.
} 
Table: 4

Values of the correlation coefficient of the selected factors (After the modification)3

\begin{tabular}{ccccc}
\hline & $\operatorname{Ln} y$ & $\operatorname{Ln} x_{2}$ & $\operatorname{Ln} x_{3}$ & $\operatorname{Ln} x_{5}$ \\
\hline $\operatorname{Ln} y$ & 1 & & & \\
$\operatorname{Ln} x_{2}$ & 0,839225 & 1 & & \\
$\operatorname{Ln} x_{3}$ & $-0,54483$ & $-0,67408$ & 1 & \\
$\operatorname{Ln} x_{5}$ & 0,644434 & 0,681325 & $-0,61668$ & 1 \\
\hline
\end{tabular}

We perform a regression analysis based on the effect of exogenous factors on the outcome factor on the basis of 3 influencing factors exept from the 2 factors excluded from the model. a nonlinear link view was used to construct an econometric model that reflected the impact of the above factor indicators on the employed population. in this case the values of the factor indices were logarithmized and the regression analysis based on these values was analyzed based on the least squares method using the Eviews 10 software package. (The graph №-5).

Table: 5

The results of determining the coefficients of the regression equation and checking the equation on the basis of criteria. ${ }^{4}$

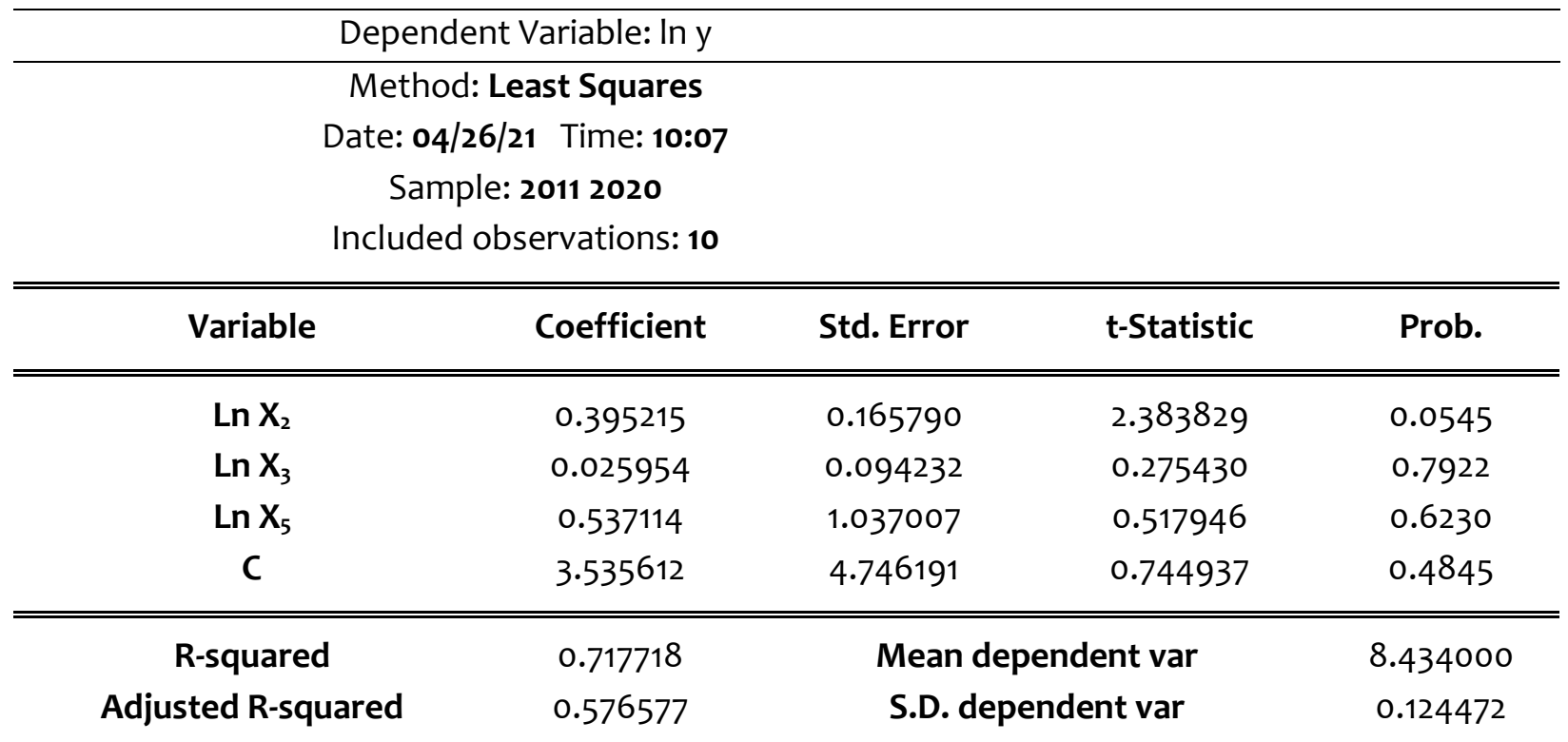

${ }^{3}$ Compiled by the author.

${ }^{4}$ Compiled by the author. 


\begin{tabular}{cccc} 
S.E. of regression & 0.080995 & Akaike info criterion & -1.899677 \\
Sum squared resid & 0.039361 & Schwarz criterion & -1.778643 \\
Log likelihood & 13.49838 & Hannan-Quinn criter. & -2.032451 \\
F-statistic & 5.085107 & Durbin-Watson stat & 2.041322 \\
Prob(F-statistic) & 0.043660 & & \\
\hline
\end{tabular}

The coefficients of the multivariate regression equation in the form of a nonlinear relationship using the Eviews 10 program and the indicators representing the importance of the regression equation and the coefficients show that this relationship is within the limits of the established criteria.

In assessing the importance and quality of a multifactor econometric model determined on the basis of regression analysis, the main focus is on the link density of the factors(ryxmultiplicity correlation), the coefficient of determination (R2), the fisher criterion,(Естат)and the student criterion (тстат).

The density of correlations with the endogenous factor of the factors influencing the number of jobs in the economy of the Republic of Uzbekistan, or the multiple correlation coefficient on the selected exogenous factors, indicates a high link density: ryx=0,8472. The value of the determination coefficient is also high depending on the correlation coefficient in the set. $(R 2=0,7177)$.the value of the fisher criterion for the defined regression equation is 344 ,Fstat $=5.085$ and the significance level of the equation is close to 0 ..

The value of the student criterion value on regression coefficients is also higher than the value of the table indicator, i.e. the value of the criterion values is at the level of demand and this indicates that the quality of the defined model is within defined limits. the DarbinWeston criterion, which indicates the presence of autocorrelation in the regression equation, is equal to $\mathrm{DW}=2.04$, which proves that the regression equation is within the optimal limit of the criterion. The degree of reliability of the identified models is high in the correlation of exogenous factors affecting the number of employed population in the economy with the time factor.

The degree of reliability of the regression equation parameters in the evaluation results on the MAPE and TIC criteria has a normal value on the criteria., MAPE- $0.624087<10$ and TIC$0.003719<1$, It was in the range of $8.3-8.4$ in 2011 and by 2020 it was 8.6 . 


\section{Picture: 1.}

\section{Regression Evaluation equation on MAPE and TIC criteria.}

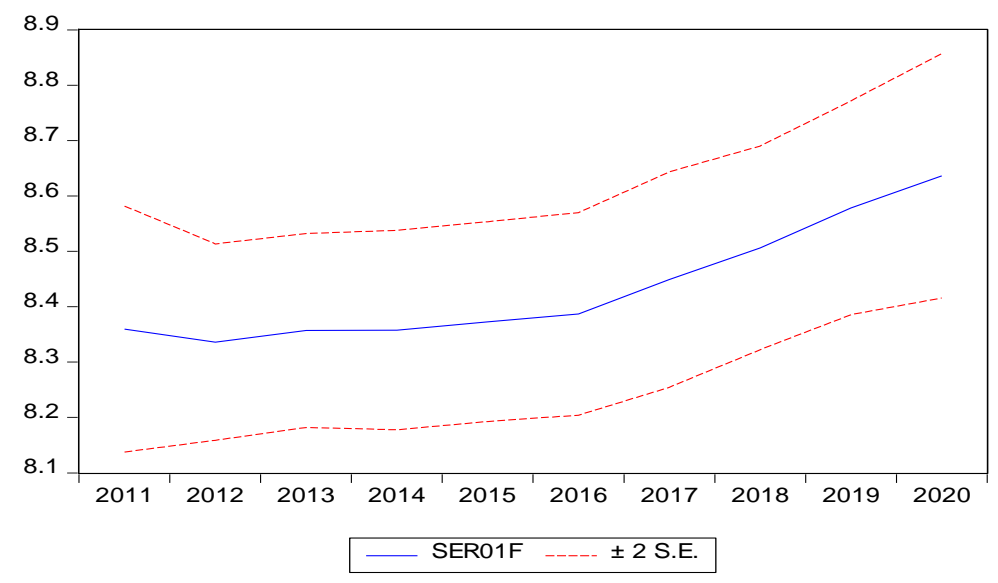

Forecast: SER01F

Actual: SER01

Forecast sample: 20112020

Included observations: 10

Root Mean Squared Error $\quad 0.062739$

Mean Absolute Error $\quad 0.052508$

Mean Abs. Percent Error 0.624087

Theil Inequality Coefficient 0.003719

Bias Proportion $\quad 0.000000$

Variance Proportion $\quad 0.082730$

Covariance Proportion 0.917270

Theil U2 Coefficient $\quad 0.641065$

Symmetric MAPE $\quad 0.624280$

After the multicollinearity test, the following modifiers were forecasted on the basis of the following modifiers $X_{2}$, (Number of enterprises operating in Uzbekistan), $\mathrm{X}_{3}$ (The average annual growth of the labor force in Uzbekistan), and $\mathrm{X}_{5}$ (consumer price index),using the least squares in forecasting the number of people employed in the informal sector of the labor market of Uzbekistan.

Based on the coefficients in Table 5, the multivariate logarithmic regression equation has the following form:

\section{$\operatorname{LnY}=0,395 \operatorname{LnX} X_{2}+0,026 \operatorname{LnX}_{3}+0,537 \operatorname{LnX}_{5}+3,536$}

the identified logarithmic regression equation was potentiated, resulting in the regression equation having the following form:

$$
\boldsymbol{Y}=\boldsymbol{X}_{2}^{\mathbf{0 , 3 9 5}} * \boldsymbol{X}_{3}^{\mathbf{0 , 0 2 6}} * \boldsymbol{X}_{5}^{\mathbf{0 , 5 3 7}} * \boldsymbol{e}^{3,536}
$$

the law of time-dependent change of indicators of each influencing factor (regression equation) was determined and on the basis of this equation the forecast indicators of influencing factors for 20212025 were determined and calculated.

$$
X_{2}=164,12+23,87 * t \text { - Number of operating enterprises }
$$

$$
\begin{gathered}
X_{3}=409,32-30,489 * t-\text { An annual incremental increase in the labor force } \\
X_{5}=104,333+0,918 * t \text { - Consumer price index }
\end{gathered}
$$


A table of necessary modifiers for forecasting employment in the informal sector in Uzbekistan is provided. Informal employment through this regression model is projected for the next 5 years.

The forecast indicators of the employed population in the informal sector of the labor market in Uzbekistan were calculated using the identified multi-factor models. (The Table 6)According to the model based on multifactor regression analysis, the number of employed people in the informal sector of the national labor market will decrease significantly over the medium term, ie in 2021-2025 compared to the actual amount in 2020.. The trend model of the consumer price index (X5) selected as the influencing factor in relation to the time factor showed an increase in the inflation rate of about $1 \%$ in the medium term. If the basic model includes the target parameters set by the Central Bank for 2021-2025, it will be possible to further reduce the number of people employed in the informal sector of the labor market and reduce it to 5101.8 thousand in 2025.

Table: 2

Forecasts of the number of people employed in the informal sector of the labor market in the Republic of Uzbekistan in 2021-2025 and the factors influencing it. ${ }^{5}$

\begin{tabular}{|c|c|c|c|c|c|c|}
\hline \multirow{2}{*}{ Years } & \multicolumn{2}{|c|}{$\begin{array}{l}\text { The number of people } \\
\text { employed in the } \\
\text { informal sector of the } \\
\text { Menhat market.mln } \\
\text { people. }\end{array}$} & \multirow{2}{*}{$\begin{array}{c}\text { Number of } \\
\text { operating } \\
\text { enterprises } A \\
\text { thousand } \\
\text { units }\end{array}$} & \multirow{2}{*}{$\begin{array}{l}\text { An annual } \\
\text { incremental } \\
\text { increase in } \\
\text { the labor } \\
\text { force.thous } \\
\text { and people }\end{array}$} & \multicolumn{2}{|c|}{$\begin{array}{c}\text { Consuemer price index, } \\
\%\end{array}$} \\
\hline & $\begin{array}{l}\text { Model- } \\
\text { based } \\
\text { forecasti } \\
\text { ng }\end{array}$ & $\begin{array}{l}\text { Target } \\
\text { parameter } \\
\text {-based } \\
\text { forecastin } \\
\text { g }\end{array}$ & & & $\begin{array}{l}\text { Model- } \\
\text { based } \\
\text { forecasti } \\
\text { ng }\end{array}$ & $\begin{array}{l}\text { Target } \\
\text { parameter } \\
\text {-based } \\
\text { forecastin } \\
\text { g }\end{array}$ \\
\hline 2021 & 5352,9 & 5266,1 & 426,7 & 73,9 & 114,4 & 111,0 \\
\hline 2022 & 5417,4 & 5255,2 & 450,6 & 43,4 & 115,3 & 109,0 \\
\hline 2023 & 5380,7 & 5171,9 & 474,4 & 13,0 & 116,3 & 108,0 \\
\hline 2024 & 5443,9 & 5184,6 & 498,3 & 8,2 & 117,2 & 107,0 \\
\hline 2025 & 5434,6 & 5101.8 & 522,2 & 3,2 & 118,1 & 105,0 \\
\hline
\end{tabular}

Using the data in Tables 1 and 6 above, we can more clearly see the pattern of change in the number of people employed in the informal sector of the labor market across the country. (The picture №-6)

\footnotetext{
${ }^{5}$ Compiled by the author
} 


\section{Picture: 6}

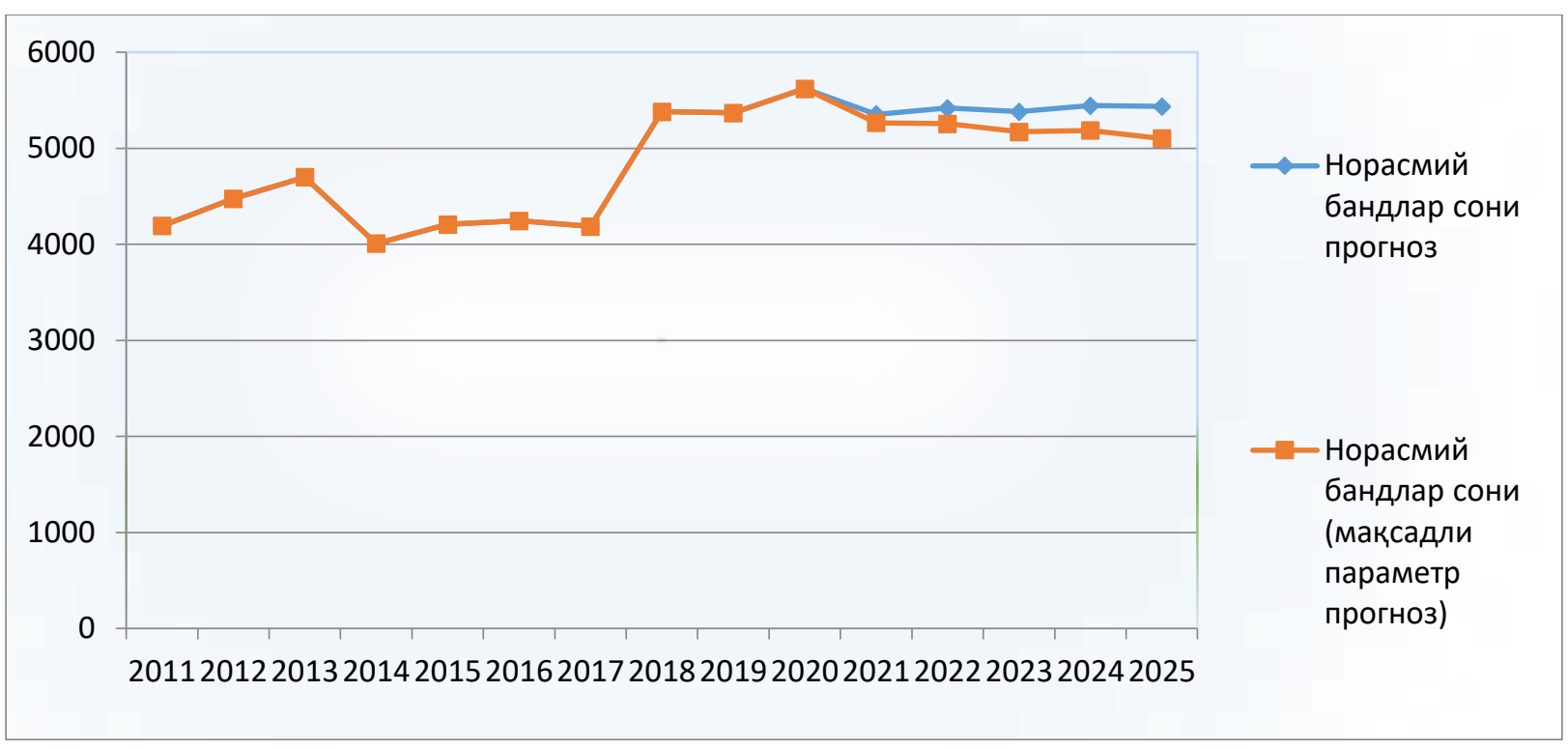

Changes in the number of employed people in the national economy. A thousand people 6

The forecast was made in two different ways:

In the first direction, the consumer price index was forecasted by the author using the following model, i.e., based on a linear equation.

In the second direction, the consumer price index is forecasted on the basis of the target parametric forecast issued by the Central Bank.

The results of the developed equation:

1. One of the main factors in the growth of the informal sector in Uzbekistan is the growth of the consumer price index, ie an increase of $1 \%$ (without changing other indicators) led to an increase in employment in the informal sector by $53 \%$. As a result of the increase in the consumer price index, the population's expenditures will increase and they will be forced to engage in additional activities or engage in informal activities in order to cover costs;

2. If the number of enterprises operating in our country increases by $1 \%$, the number of people employed in the informal sector will increase by $39 \%$. Basically, even if the enterprises are registered as a legal entity, it is possible to operate informally in the enterprise, that is, to operate without an employment contract;

3. In the period from 2011 to 2020 , our labor resources have been declining compared to last year. A $1 \%$ increase in labor resources

\footnotetext{
${ }^{6}$ Compiled by the author.
} 
will lead to a 2.5 increase in employment in the informal sector.

\section{CONCLUSIONS AND SUGGESTIONS}

Based on the results of a multi-factor analysis of the number of people employed in the informal sector of the national labor market, the following conclusions are summarized:

1. The pattern of change in the number of people employed in the informal sector of the labor market (trend model) can be determined in the form of a nonlinear model based on multifactor econometric analysis. This requires the use of PEST analysis (analysis of political, economic, social and technological factors) rather than SWOT-analysis, in contrast to the specific production (service) sectors of the endogenous factor( the number of people employed in the informal sector of the labor market.) and exogenous factors influencing its change.

2. According to the leading experts of the state socio-economic systems, today there are 5 important exogenous factors as the main factors influencing the change in the level of employment in the informal sector of the national labor market are set. A certain amount of change (increase or decrease) in the indicators of this factor leads to a significant change in the endogenous variable.

3. The model shape was chosen in the form of a nonlinear model because the factor indicators in the trend model, which represent the effect of the factors influencing the outcome factor, were not homogeneous.
Based on the above conclusions and (3.2), it is expedient to reduce the number of people employed in the informal sector of the labor market, ie to legalize their activities and transfer them to the official sector in the following areas:

- Establishment in the status of a legal entity of enterprises associated with the name of the year and established in the development of sectoral and regional programs leads to the official registration of employees hired by them. Entrepreneurs registered as sole proprietors have limited opportunities to adequately control the process of official registration of hired labor;

- In the process of planning demographic changes and the formation of the balance of regional labor resources, it is advisable to plan in advance the labor resources required for sectors of the economy for 16 18 years. Because the rate of additional annual growth of labor resources in our country is declining from year to year, and this situation will lead to a shortage of labor resources, as in the countries of the European Union;

- The practice of targeting the inflation rate, which is one of the macroeconomic indicators at the national level, allows to control the inflation rate in the country by specific means, and it will be possible to stabilize the situation in the labor market by ensuring that this indicator is within the required range..

- Another factor that leads to an increase in the number of people employed in the informal sector of the labor market is the tax imposed on the income of individuals and the introduction of benefits for 
individuals with a minimum income in the taxation system will lead to their transition from the informal sector to the formal sector;

- Another way to reduce the number of people employed in the informal sector of the labor market (especially in construction and service enterprises) is the calculation of informal employment, and the strengthening of economic and administrative sanctions against such enterprises will dramatically reduce the number of informal hires.

Using the results of the above analysis and the recommendations for reducing the number of people employed in the informal sector of the labor market in the proposed practice, further reduce the level of informal employment by managing and coordinating factors affecting the level of informal employment in the national labor market, ie legalization of informal employment improves their ability to relocate to the formal sector of the economy.

As a result of the activities in these areas, the legalization of informal employment in our country will accelerate to some extent.

\section{REFERENCES}

1. Address of the President of the Republic of Uzbekistan to the Oliy Majlis. 2020y. Electronic resource: https://www.norma.uz/uz/bizning_sharhla r/2020_yil_ilm_marifat_va_raqamli_iqtisod ietni_rivojlantirish_yil.

2. Resolution of the Cabinet of Ministers No. 1011 of December 22, 2017: www.lex.uz.
3. Resolution of the President of the Republic of Uzbekistan dated March 5, 2019 No PR4227: www.lex.uz.

4. Resolution of the Cabinet of Ministers No. 566 of July 9, 2019: https://www.lex.uz.

5. Resolution of the President of the Republic of Uzbekistan No. PP-4742 of June 8, 2020: www.lex.uz.

6. Qoraboyev N.P. "Issues of informal employment in the Republic of Uzbekistan". Journal of Economics and Education, No. 2, pp. 83-86. Tashkent-2019.

7. (EViews10):Interpret VECM, Forecast Error Variance Decomposition.

8. Law of the Republic of Uzbekistan "On the State Budget of the Republic of Uzbekistan for 2021" Law No. 657 of December 25, 2020. www.lex.uz.

\section{Electronic resources:}

- National Database of Legislation of the Republic of Uzbekistan.www.lex.uz.

- The official website of the State Statistics Committee of the Republic of Uzbekistan: www.stat.uz.

- Official website of the Ministry of Employment and Labor Relations of the Republic of Uzbekistan:www.mehnat.uz.

- The Central Bank of the Republic of Uzbekistan: https://cbu.uz/oz/.

- Ministry of Economic Development and Poverty Reduction of the Republic of Uzbekistan: www.mineconomy.uz/ru. 